Bond University ePublications@bond

Sports Law eJournal

Faculty of Law

$12-7-2012$

\title{
Australian sport and the Commonwealth constitution
}

Chris Davies

James Cook University

Follow this and additional works at: http://epublications.bond.edu.au/slej

Part of the Entertainment, Arts, and Sports Law Commons

\section{Recommended Citation}

Chris Davies. (2012) "Australian sport and the Commonwealth constitution" Sports,, 1-8: ISSN 1836-1129.

http://epublications.bond.edu.au/slej/15 


\title{
Australian sport and the Commonwealth constitution
}

\begin{abstract}
Sports law generally consists of areas of law applied to a sporting context, although now we are seeing the development of a lex sportiva. One area of the law that has rarely been applied to sport is constitutional law. However, recent High Court of Australia cases have examined the application of s 92 of the Constitution of Australia to sports gambling.
\end{abstract}

\section{Keywords}

Australian, sport, Commonwealth, constitution

\section{Disciplines}

Entertainment, Arts, and Sports Law 


\title{
AUSTRALIAN SPORT AND THE COMMONWEALTH CONSTITUTION
}

\author{
by CHRIS DAVIES*
}

Sports law generally consists of areas of law applied to a sporting context, although now we are seeing the development of a lex sportiva. One area of the law that has rarely been applied to sport is constitutional law. However, recent High Court of Australia cases have examined the application of s 92 of the Constitution of Australia to sports gambling.

\section{INTRODUCTION}

While sports law can be viewed primarily as all areas of the law applied to the sporting context, one area not usually associated with sport is constitutional law. However, the High Court has recently handed down three decisions in sport related cases involving questions of the application of the Commonwealth Constitution. ${ }^{1}$ These three cases, Betfair Pty Ltd $v$ Western Australia, ${ }^{2}$ Betfair Pty Ltd $v$ Racing New South Wales ${ }^{3}$ and Sportsbet Pty Ltd $v$ New South Wales ${ }^{4}$ all involved the issue of whether various pieces of legislation relating to online betting were in breach of s 92, or its Northern Territory equivalent. This article examines these three decisions, together with what can be considered as the only other sports related High Court constitutional law decision, namely the Adamson ${ }^{5}$ case. The underlying theme to this examination will be the application of the Commonwealth Constitution to Australian sport. First, however, here is a brief overview of the relevant sections of the Commonwealth Constitution.

\section{THE COMMONWEALTH CONSTITUTION}

Australia is a federation, formed in 1901 from the former colonies of New South Wales, Tasmania, Victoria, South Australia, Western Australia and Queensland. Each of these former colonies is now a state within the Commonwealth of Australia, each retaining its own constitution, and with that, plenary law-making powers, though any state law must not be inconsistent with any Commonwealth law. ${ }^{6}$ The formation of the Commonwealth required a written constitution in order to provide a framework within which the powers of the states and the Commonwealth could be established.

Section 51 sets out most of the Commonwealth powers. Section 51 (i), for instance, provides the Commonwealth with law making powers on trade and commerce with other countries, and also between the states. Taxation powers, meanwhile, are created by s 51 (ii), while the corporations

\footnotetext{
* Associate Professor, School of Law, James Cook University

Constitution of Australia Act 1901 (UK).

Betfair Pty Ltd v Western Australia (2008) 234 CLR 418.

[2012] HCA 12.

${ }^{4}$ [2012] HCA 13.

$5 \quad R v$ Federal Court of Australia and Adamson: ex parte Western Australian Football League Inc (1979) 143 CLR 190.

6 Section 109 of the Constitution of Australia Act 1901 (UK).
} 
power (s $51(\mathrm{xx})$ ) provides the Commonwealth with powers with respect to international corporations, and trading and financial corporations formed within Australia. The main question in regard to this section is what constitutes a trading corporation, with Adamson the leading case on this issue. The Betfair cases, meanwhile, involved issues relating to s 92, which states that 'trade, commerce and intercourse between the states ... shall be absolutely free.' Cole $v$ Whitfield ${ }^{7}$ is considered the leading case for this section, and it established that s 92 prohibits measures that place discriminatory protectionist burdens on interstate trade and commerce. Section 92 has, in fact, been the most litigated section of the Commonwealth Constitution. ${ }^{8}$ It is not surprising therefore that sports law related s 92 cases have now reached the High Court. Before examining these cases, however, the article will first examine the earlier Adamson case.

\section{THE ADAMSON CASE}

\section{A Background Facts}

Brian Adamson was a registered player with West Perth in the Western Australian National Football League (WAFL). He then received an offer to play for Norwood in the South Australian National Football League (SANFL). Both clubs were incorporated under the relevant state acts, and were also members of the National Football League of Australia, itself a company limited by guarantee and incorporated under the Companies Act 1961 (Vic). ${ }^{9}$

Adamson moved to South Australia and applied to WAFL for a clearance to enable him to play for Norwood, since under the National Football League rules the clearance had to be approved by WAFL. West Perth opposed granting Adamson a clearance and WAFL therefore refused his application. Adamson then commenced legal action, claiming that the club and the leagues were trading corporations and that, in relation to the clearance application, had been in breach of $\mathrm{s} 45$ of the Trade Practices Act 1974 (Cth). ${ }^{10}$ West Perth and WAFL obtained an order nisi for prohibition in the High Court to prevent the Federal Court from proceeding with the application. This was on the grounds that the Federal Court had no jurisdiction to make the orders because neither organisation was a trading corporation, and neither was involved in interstate trade and commerce in refusing the clearance. ${ }^{11}$

When the matter was heard in the High Court the major question was whether the two leagues and the club were in fact trading corporations. Both the WAFL and the SANFL stated that their objectives were to promote, control and manage the sport, ${ }^{12}$ while West Perth's objectives were providing facilities for playing the game as well as recreation and sporting facilities for its members. ${ }^{13}$ Under the then existing interpretation by the High Court none would have been considered trading corporations, since the established test at the time was to examine the purpose

\footnotetext{
(1988) 165 CLR 360.

8 Clarke, Keyzer and Stellios, Hanks' Australian Constitutional Law: Materials and Commentary (8 ${ }^{\text {th }}$ ed, LexisNexis, 2009) 797-8.

$9 \quad R v$ Federal Court of Australia and Adamson: ex parte Western Australian Football League Inc (1979) 143 CLR 190, 194.
}

10 Ibid 195.

11 Ibid 192.

12 Ibid 234.

13 Ibid 235. 
of the corporation. ${ }^{14}$ The other issues were whether the refusal to grant a clearance was conduct in relation to interstate trade and commerce under s 51 (i), and whether the Federal Court had jurisdiction to make orders in the case.

\section{B The High Court Decision}

Chief Justice Barwick stated that to enforce s 45 'the body sought to be affected must be a trading corporation within the ampit of constitutional power, ${ }^{\prime 15}$ and it will satisfy the description trading corporation if trading is a substantial corporate activity'. ${ }^{16}$ His Honour noted that football can be purely amateur, 'played solely for its own stage as a pastime'. ${ }^{17}$ However, the case concerned a professional league involving players who were employees on wages. Barwick CJ then held that, 'the presentation of a football match as a commercial venture for profit to the promoting body is an activity of trade'..$^{18}$ Mason J also held that the trading activities of the two leagues 'as revealed by the evidence are so extensive as to leave no doubt in my mind that they are trading corporations'. ${ }^{19}$ His Honour noted that the total revenue received by WAFL in 1976 was $\$ 1,290,196$ - while in 1977 it had been $\$ 1,630,314$. This revenue came from a variety of sources: gate receipts, television rights, sponsorship, catering rights and the sale of weekly programs. Similar sources and levels of income were also noted for the SANFL. Justice Mason likewise held West Perth to be a trading corporation, as it also generated significant income, mainly from selling meals and liquor to its members. ${ }^{20}$ Thus, the test that was developed in Adamson was no longer looking at the purpose of the corporation, but whether trading formed a 'sufficiently significant proportion' of the overall activities of the corporation. ${ }^{21}$

However, while it was held by a 4:3 majority that the three organisations were trading corporations, the SANFL and WAFL were not considered to be involved in interstate trade 'in any shape or form'. ${ }^{22}$ However, Adamson was successful in that the order nisi for writ of prohibition was discharged. ${ }^{23}$

\section{THE ONLINE BETTING CASES}

\section{A Betfair Pty Ltd v Western Australia}

Betfair held a gaming licence under s 761 of the Gaming Control Act 1993 (Tas). Since 2006 it had operated a betting exchange scheme through which it could accept an offer for a bet, made by telephone or by computer, for Australian racing events. If accepted, a message would be sent via the internet to the customer's computer from a web server on Betfair's computer in Tasmania.

$14 \quad R v$ Trade Practices Tribunal: Ex parte St George County Council (1974) 130 CLR 533.

$15 \quad R v$ Federal Court of Australia and Adamson: ex parte Western Australian Football League Inc (1979) 143 CLR 190, 207.

16 Ibid 208.

17 Ibid 210.

18 Ibid 211.

19 Ibid 236.

20 Ibid 236.

$21 \quad$ Ibid 233.

22 Ibid 237.

23 Ibid 237, 240, 241. 


\section{AUSTRALIAN SPORT AND THE COMMONWEALTH CONSTITUTION}

The second plaintiff, Matthew Erceg, was a resident in Western Australia and was a registered customer with Betfair, placing bets on races in Western Australia and other places in Australia. ${ }^{24}$

The Western Australian government then introduced the Betting and Racing Legislation Amendment Act 2006 (WA) which amended the Betting Control Act 1954 (WA) by inserting a new s 24 (aa). This section made it an offence to make bets through a betting exchange. A new s 27D (1), meanwhile, made it an offence for an unauthorised person to make 'available a WA race field in the course of business' ${ }^{25}$ Betfair applied for approval under this section to make such WA race fields available, but this was refused by the WA Minister for Racing and Gambling. ${ }^{26}$ As result, Betfair lost Erceg and all its other WA customers. It therefore sought a declaration that the amendments were invalid as being contrary to s 92 of the Australian Constitution. ${ }^{27}$

The High Court held that both s 24 (1aa) and s 27D (1) were invalid by means of s 92. Section 24 (1aa) was invalid because it operated to protect established wagering operators in WA - licensed bookmakers, operators of on-course totalisators and Racing and Wagering WA - from competition that Betfair would otherwise present. ${ }^{28}$ Gleeson CJ stated:

The effect of s 24 (1aa) is to prohibit Betfair, an out-of-state wagering operator, from providing a betting exchange for registered players in WA, leaving the in-state operators to supply customers with their services without the competition to their revenues which Betfair would present. This is another discriminatory burden of a protectionist kind. ${ }^{29}$

Section 27D (1) was meanwhile held to be invalid under s 92 to the extent it would apply to Betfair's conduct in making available a WA race field, by means of telephone or internet communications, between its Tasmanian premises and another state. It therefore burdened interstate trade and commerce, directly, by denying Betfair the use of an element of its trading operations, and indirectly by denying Betfair's customers information in regard to WA race fields. There was therefore a competitive disadvantage to Betfair, and at the same time, an advantage to WA wagering operators. ${ }^{30}$ It was also held that an objective of the new amendments, namely to protect state revenue from instate betting operators, did not justify a law which discriminated against interstate trade, and it was not necessary for the protection, or preservation, of the integrity of the racing industry in WA. ${ }^{31}$

Betfair was to later take legal action in regard to racing industry legislation in NSW, the matter again reaching the High Court.

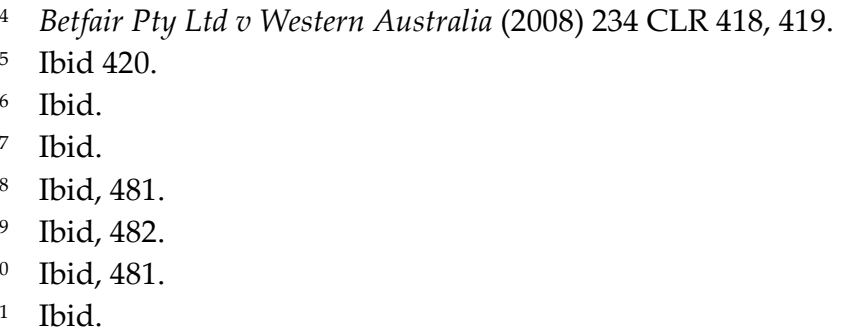




\section{B Betfair Pty Ltd v Racing New South Wales}

Betfair's litigation concerned Part 4 of the Racing Administration Act 1998 (NSW) (RAA) over the validity of fees imposed by and payable to Racing New South Wales (RNSW) and Harness Racing New South Wales (HRNSW). ${ }^{32}$ It was noted that the litigation was a 'sequel only in a general sense' to the earlier Betfair $v$ Western Australia, the difference being the NSW legislation did not 'erect against a betting exchange operator a barrier to entry' by making it an offence to place bets with an interstate betting exchange. Betfair, however, again relied on s 92 in arguing that the fees imposed in NSW were invalid ${ }^{33}$ to recover the fees it had already paid, ${ }^{34}$ which represented $1.5 \%$ of the approved holder's net turnover. ${ }^{35}$

The High Court confirmed that $s 33$ of the RRA made it an offence for a wagering operator to use NSW race field information, unless an approval was obtained under s 33A. ${ }^{36}$ Also of relevance were the Racing Administration Regulations 2005 (NSW) (the Regulations), Clause 20 of which stated that in determining an approval, the RNSW and HRNSW were not to take into consideration the location within Australia of the applicant. The High Court noted that s 33A (2) enabled the RNSW and HRNSW the power to grant approval to use NSW race field information, subject to the condition of paying the agreed fees, and that Betfair's case was that to be valid 'the sub-section must be read as not authorising provisions in the Regulations which are obnoxious to the freedom required by s 92'. ${ }^{37}$ The second aspect of Betfair's case was that the fees imposed upon it were obnoxious in this sense, and as a consequence were beyond the power conferred by the Regulations upon RNSW and HRNSW. ${ }^{38}$

The High Court said that in Betfair Pty Ltd $v$ Western Australia it had been held that there were 'three species of the genus "wagering operators" ' - namely bookmaker, a totalizator and a betting exchange - and that profit margins may be assessed in different ways. Further, there was a difference between the fixed odds betting of Betfair and that of the more traditional bookmaker. Betfair did not hold a 'book', nor did it carry any risk on the outcome of the event. Instead it charged a commission of between $2-5 \%$ on the outcome of bets it matches on its computers. The High Court then stated that the standard fees at issue in the case were made in relation to the total amount of wagers made. It had 'several distinct features', one being that they were 'neutral as between the various wagering operators', the second being that they were imposed without distinction as to whether the wagering operators and customers were located in NSW or not. The third feature was that 'no distinction is drawn between the use of NSW race field information in wagering activities which form part of trade between the States and those which do not do so' ${ }^{39}$

The High Court noted that the Full Court of the Federal Court had accepted that the licence fee had a greater impact upon Betfair's business than 'upon those of its non-betting competitors', and

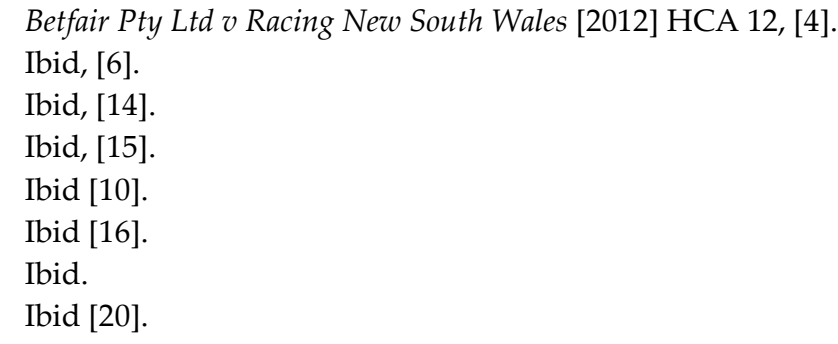


that this might tend to support the proposition that the fee is discriminatory. ${ }^{40}$ However, it was held by the High Court that 'not every measure which has an adverse effect between competitors will attract the operation of s 92', and that Betfair had to establish that the fee conditions were unauthorised because 'their practical effect is to discriminate against interstate trade and thereby protect intrastate trade of the same kind' ${ }^{41}$ It was then held that Betfair's different fee structure was not a relevant difference, ${ }^{42}$ nor had Betfair demonstrated that 'the likely practical effect of the imposition of the fees will be losses of market share or profit or on impediment to increasing that share. ${ }^{43}$ Betfair's appeal was dismissed..$^{44}$

\section{Sportsbet Pty Ltd v New South Wales}

Sportsbet is a Northern Territory based company with an office in Darwin. It holds a sports bookmaking licence under s 90 of the Racing and Betting Act (NT). This licence authorised it to accept bets by telephone or by means of the internet for sporting events and races, including horse and harness racing in NSW. For the latter it used NSW race field information, ${ }^{45}$ and was granted approval by RNSW and HRNSW to use such information, subject to the condition of paying a fee on its 'wagering turnover'. ${ }^{46}$ There was an exception for all wagering operators in that the first \$5m turnover with RNSW, and \$2.5m with HRNSW, were not subject to the fees. Sportsbet, however, like Betfair, sought to have s 33 and s 33A of the RAA declared invalid, and again, like Betfair, sought to have a decision by the Full Court of the Federal Court overturned by the High Court. The two cases - Betfair and Sportsbet - were heard concurrently.

In Sportsbet, the High Court held that s 49 of the Northern Territory (Self-Government) Act 1978 (Cth) was the relevant section, and this reproduced, except in the use of the word 'territory' instead of 'state', the terms of s 92 of the Commonwealth Constitution. Thus, the examination of $\mathrm{s}$ 49 involved following 'the course of decisions construing s 92', and that it was 'a "positive rule" relating to the government of the Territory, and thus supported by s 122 of the Constitution'. ${ }^{47}$ The issue in the case, therefore, was whether the condition requiring payment of fees under the RRA 'alter, impair or detract from the Self-Government Act'. ${ }^{48}$

The High Court held that the legal effect of s 33 and s 33A of the RRA was not 'discriminatory in a protectionist sense'. The question was then 'whether, as a matter of its practical operation or effect, the Act does have that character'. ${ }^{49}$ It was held that the 'practical operations of the thresholds is not to provide a protectionist measure to insulate NSW on-course bookmakers from the economic burden of the fee' since 'both intrastate and out of State competitors could benefit from the threshold'. ${ }^{50}$ This then left the contention that the TAB was insulated from its liability in regard to the fees imposed by RNSW and HRNSW. This was in respect to the Racing Distribution

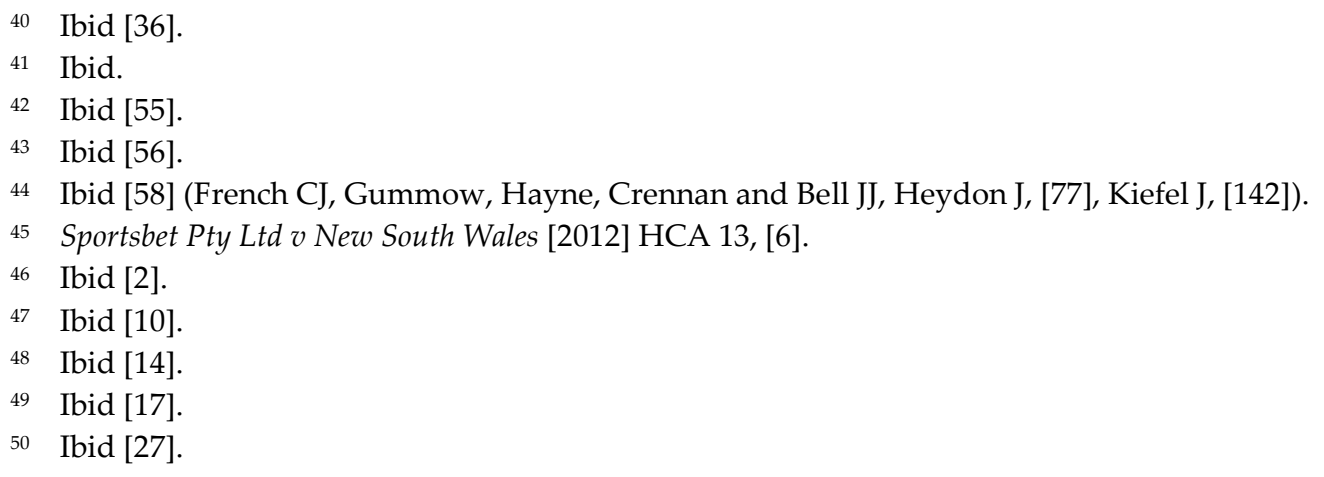


Agreement dated 11 December 1997, later amended 22 December 2004, Clause 8.2 of which entitled TAB to a 'royalty free licence' in regard to using NSW race information due to the fact that the TAB paid 'substantial fees' in regard to 'all the services' provided for under the agreement. These fees, it was noted, meant that the TAB paid $\$ 19.8 \mathrm{~m}$ between 1 September, 2008, and 30 June, 2009 , with this exceeding $1.5 \%$ of its turnover. ${ }^{51}$ It was then held that the operation upon $\mathrm{TAB}$ of being released from the fees on its turnover during this time period 'cannot be said to have produced discrimination against interstate trade, let alone discrimination of a protectionist nature'. ${ }^{52}$ Thus, 'the practical operation' of the RRA 'with respect to the fees payable by Sportsbet was not to alter impair or detract from the "positive rule" mandated by s 49 of the Self-Government Act'. ${ }^{53}$ Sportsbet appeal was therefore dismissed. ${ }^{54}$

\section{CONCLUSION}

When examining the application of the law to the sporting context, it should be kept in mind that any time it involves a Commonwealth statute there will be a constitutional basis to it since, for the law to be valid, the legislation must fall under one of the heads of power in s 51, or alternatively be covered by s 61 . One of the major areas of sports law is undoubtedly anti-doping and, within Australia, the legality of the drug testing of athletes is derived from the Australian Sports Anti-Doping Authority Act 2006 (Cth). To be constitutionally valid it must be covered by s 51, with the external affairs power, s 51 (xxix), being the most likely since drug testing of athletes involves international agreements.

The Adamson case, meanwhile, produced what is now the standard definition as to what constitutes a trading corporation. While it changed the interpretation of s 51 (xx) from the purpose test to an activities test, the factual background of the case was also highly beneficial to constitutional law. This is because the specific facts indicate that what constitutes 'trading' will be broad, and any organisation that generates significant income, even if it claims not to be intending to do so, will now be considered a trading corporation. It is also suggested, however, that Adamson should be viewed as an example of sports law contribution to constitutional law in Australia, rather than being a significant sports law case.

Gambling in sport has attracted a lot of attention in recent years after incidents of match and spot fixing led to both court cases and suggested legislative responses. ${ }^{55}$ What the cases involving Betfair and Sportsbet have also shown is that there have been constitutional questions regarding the operation of online sports betting. It is suggested, however, that these are cases involving questions of constitutional interpretation that just happened to have a sports related context, rather than having any real impact on the development of sports law or a lex sportiva - a sports legal order - in Australia and worldwide. ${ }^{56}$ That is not to say that it is unlikely to be many future

51 Ibid [30]-[31].

52 Ibid [36].

53 Ibid [37].

54 Ibid [37] (French CJ, Gummow, Hayne, Crennan, Kiefel and Bell JJ, Heydon J, [53]).

55 Threats to the integrity of professional sport in Australia: http://www.crimecommission.gov.au/publications/crime-profile-series-fact-sheet/threats-to-integrityprofessional-sport-australia.

56 There is the gradual development of transnational judicial activity, led by sports tribunals, principally the CAS, the Court of Arbitration for Sport. See, generally, Lorenzo Casini, 'The Making of a Lex 


\section{AUSTRALIAN SPORT AND THE COMMONWEALTH CONSTITUTION}

constitutional cases involving a sporting context. Sports law is developing and spreading in influence, as an area of legal demand and social and diplomatic importance..$^{57}$ Its transnational reach and deep influence may well throw up more constitutional law issues.

Sportiva: The Court of Arbitration for Sport “Der Ernährer"' (3 June 2010). Available at SSRN: http://ssrn.com/abstract=1621335 or http://dx.doi.org/10.2139/ssrn.1621335.

57 The Court of Arbitration for Sport (the CAS) has succeeded with its cooperative, transnational model of adjudication, its development of common legal principles and its interpretation and growth of global rules in sport. We see the development of a body of sports law across the globe in areas such as doping, sports-related intellectual property and the development of the right to sport. 